\title{
Effect of Micro-finance on Women's Economic Empowerment A Case-Study of Omo-microfinance Institution, Lemo District, Hadiya Zone, Southern Ethiopia
}

\author{
Nuri Lefebo Toramo (PhD) \\ Assistant professor, Wachemo University, Ethiopia \\ Meaza Melese \\ Lecturer, Wachemo University, Ethiopia
}

\begin{abstract}
Micro-finance institutions have made significant contributions to the livelihoods of many people through the provision of financial and supporting services to the poor, especially women in rural environments. Thus, it is understood that micro-financing, as a development strategy, empowers women who were hitherto marginalized, and as such, were restricted from participating in the social, economic and political activities of their societies. This study examined the effect of micro-financing service on women's economic empowerment in lemo district, hadiya zone, southern Ethiopia. Data was collected from a total of 156 rural women. The empirical analysis of the study was conducted using both descriptive statistics and binomial logit regression analysis. The results of the study indicate that the micro-financing scheme has a positive impact on women's economic empowerment as measured by the increased participation of women in household decision-making. micro-financing program has had a positive impact on the living conditions of its clients. Compared to the Incoming clients and non-clients, matured clients of micro-financing have improved their household incomes, asset possession levels, and savings habit; thereby positively affecting their ability to fully participate in household decision-making. However, the impact of improvement of the above three variables; income, asset possession and savings habit, does not significantly affect the variable "decision making on household large sales", which was used as an indicator of women's economic empowerment in the regression analysis. The implication of the findings is that giving women access to resources does not always mean empowering them economically, unless they can also exercise full control, and make important decisions, over their resources. Thus, beyond financial support, the contribution of micro-finance services to women's economic empowerment should be enhanced through a combination of more effective support services of MFIs or linkages should be made with services provided by other agencies like the Woreda Women's Affaire' Office and other gender-focused organizations.
\end{abstract}

Keywords: micro-finance, women, binomial logistic regression, Ethiopia.

DOI: $10.7176 / \mathrm{JESD} / 10-13-03$

Publication date:July $31^{\text {st }} 2020$

\section{INTRODUCTION}

Micro-finance institutions have made significant contributions to the livelihoods of many people through the provision of financial and supporting services to the poor, especially women in rural environments. Thus, it is understood that micro-financing, as a development strategy, empowers women who were hitherto marginalized, and as such, were restricted from participating in the social, economic and political activities of their societies (Padma and Getachew, 2004).

The livelihood of the majority of the population of Southern Ethiopia is highly dependent on agriculture. Agriculture is still practiced based on traditional farming methods, is typically nature-dependent and generally unimproved; thereby subjecting the people to very unreliable living conditions(USAID, 2005). Accordingly, it is often articulated that the level of poverty in the Southern Region keeps people trapped in marginal existence with emphasis only on dayto- day survival, leaving little opportunity to accumulate capital either to invest in improving their livelihood or as a reserve to enable them cope during hard times. Opportunities for off-farm and alternative employment are still limited in the region (Wolday Amha, 2001). Further more, the longstanding population settlement, over-cropping, and little or no improvement in traditional farming practices have resulted in considerable environmental degradation, leading to a decrease in agricultural production and leaving the population highly vulnerable to recurrent drought and famine.

To this end, the limitation of the agricultural sector in creating sustainable livelihoods and the need for developing alternative income generating opportunities is increasingly being recognized by the Ethiopian government, both at federal and regional levels, as well as by donor countries. For instance, since 1997, the Amhara National Regional State has introduced a new food security program called "the Integrated Food Security Program" whereby, it has developed five strategies (or program components) that have focused on increasing the capacity of households for improved production and productivity; creating alternative income sources through the 
expansion of off-farm employment opportunities; developing human resource and institutional capital, as well as market infrastructure and rural finance; introducing and developing sustainable land husbandry practices; and rural product and financial market development (Sorensen, 2001).

Microfinance development and expanding opportunity for off-farm and non-farm activities are thus two of the crucial strategies pointed out by the region's food security program to change the living conditions of poor people, particularly women. However, the progress so far made, in terms of studying the extent of implementing those strategies as well as benefits obtained, remain grossly inadequate.

\subsection{Statement of the Problem}

Women constitute about 50 percent of the Ethiopian population and they involves in different sectors of the economy. Although poor women are engaged in heavier and highly time-consuming work loads, they never obtain the commensurate earnings. This leads them to be highly dependent on their husbands. The burden is worse in rural Ethiopia where peasant women have no alternative to generate their own income and to be self-reliant. Even the main asset of the agricultural economy - land - is typically held in the name (ownership title) of their husbands except in some parts of Tigray and Amhara, where the land ownership title is held in the name of both husband and wife.

Due to cultural problems, un-participatory policies and lack of awareness, women continue to be burdened with back-breaking domestic chores and unimproved heavy agricultural activities for long periods of time. Women in Ethiopia have not been exposed to the economic opportunities that would enable them practice alternative income-generating activities. This lack of alternative income sources constrains women to be very much dependent on their husbands and to have low participation in household decision-making. Besides, women have no access to networks to share experience of the world outside the home.

But recently, many scholars, policy-makers and development planners have started advocating the important role of the emerging new phenomenon, microfinance program, for the advantage of poor Ethiopian women. Microfinance institutions in the country are formed with major objectives of poverty alleviation and women empowerment to mention few. The extent of success on the objectives and activities of MFIs' is but subject to the level of real changes brought on the targeted group of population.

However, studies that critically assess the effect of micro-finance on women's economic empowerment are so far limited in the country. This is perhaps due to the fact that both micro-finance development and priority attention to women's economic empowerment are new, and are now currently recognized as important strategies in the process of policy development in Ethiopia.

Therefore, this study is intended to generate evidentiary information about the effect of micro-financing on the economic empowerment of rural women, based on a case-study of women microfinance clients in Lemo Woreda of the Hadiya Zone,southern Ethiopia.

\subsection{Objective of the Study}

The main objective of the study is to examine the effect of microfinance on the economic empowerment of rural women. The specific objectives were:

- To assess the effect of microfinance on women's access to, and control over, assets.

- To examine the effect of microfinance on raising women's participation in household decision-making.

- To assess the role of microfinance services in developing women's saving habit.

- To assess the role of microfinance services in improving women's come.

\section{LITERATURE REVIEW}

\subsection{The Concept and Definition of Microfinance}

Microfinance has undergone several transformations in terms of concept, services type and approaches/modes of provision. Indeed, microfinance is said to be a new and emerging field in which there is still a lot to learn (Dunford, 2000). Although an evolving concept, microfinance has been recognized as a development approach intended to benefit low-income women and men (Ledgerwood, 1999; Otero, 1999).

In using the term microfinance, there exists, however, some confusion. The point of confusion lies on the nature of clients served and types of services offered. Regarding the nature of clients, though different scholars stated microfinance program in different perspectives, most of them tend to believe that the program has emerged to help the poorest sections of the society. Others, however, argue that since it is rather not easy in practice to consistently serve clients that are living below the poverty line, micro-financing is meant for those who are presumed to be able to repay loans (Meagher, 2002).

By taking the types of services into consideration, microfinance is often defined as "lending small amounts of money for short periods with frequent repayments" (Ibid, 2002). Such understanding equates the concept with micro-credit, which is rather a part of microfinance service, and thus, microfinance is much more than simply credit (McGuire and Conroy, 2002). In some other cases, microfinance is conceived as the provision of credit and 
saving services only. This again limits the concept to micro-banking, or simply banking services. But "microfinance is not simply banking; rather it is a development tool" (Ledgerwood 1999).

In broader understanding, Ledgerwood conceived that microfinance refers to the provision of financial services to low-income clients, including the selfemployed. Financial services generally include savings and credit; however, some micro-finance institutions (MFIs) also provide credit cards, payment services, money transfers, and insurance services. Besides, many MFIs undertake social intermediation services such as group formation, development of self-confidence, and training in financial literacy and management capabilities among members of a group. "Thus, the concept of microfinance often includes both financial and social intermediations." (Ibid, 1999).

A more useful and perhaps practical definition of microfinance, for the purpose of this thesis, is given by Meyer and Nagarajan (2000), which defines microfinance as “... the provision of a broad range of financial services such as deposits, loans, payment services, money transfer, and insurance to low-income households and their micro-enterprises". Related to this, McGuire and Conroy (2002) indicated that low-income households do not generally have access to financial services but they have considerable effective demand for such services.

Thus, microfinance refers to the provision of financial services, usually in the form of small- sized financial transactions, to people who usually fall outside the reach of formal finance. They tend to be the poorest members of all societies. Commercial banks usually ignore them to avoid high transaction costs of servicing small loans and savings deposits. Moreover, most of the poor do not possess assets normally demanded as collateral, and they are perceived as being too risky to be granted loans (Meyer, 2001).

\subsubsection{The Concept and Definition of Empowerment}

The verbal definition of empowerment is related to the word power. In English, the concept leans on its original meaning of investment with legal power, i.e. permission to act for some specific goal or purpose (Batliwala, 1995). Rowland (1997) has also conceived empowerment, giving greater emphasis on power. According to him the power process involves four dimensions, i.e. Power from within: individual changes in confidence and consciousness; Power to: capability and capacity improvement as in skills, income, and market and job access; Power over: overcoming subjugation at household, community and macro level; Power with: networking, partnership, collaboration and joint action to challenge and change power relations.

However, the term empowerment has different meanings in different sociocultural and political contexts, and does not translate easily into all languages. In connection with this, Mayoux $(2001,2002)$ stated that although a number of works have been done on the concept and indicators of empowerment, it is a loaded term that means many things to different people and has subsequently gained a language command within the development discourse.

Narayan (2002), conceived the subject in its broadest sense in which empowerment is the expansion of freedom of choice and action. It means increasing ones authority and control over the resources and decisions that affect ones life. In addition, Borchgrevink et al (2005) indicated that empowerment's core meaning refers to a process whereby a person or a group becomes less dependent on external circumstances (force) and more capable of influencing key processes relating to the situation of his/her/their life and livelihood.

Empowerment underpins the process of change that determines the dominant pattern of power relations by strengthening resistance and the need to disengage from power networks using an inherent stimulated autonomy i.e., reinforcing claim-making capacity (Villarreal, 1994: 227). Empowerment includes change and transformation from one level or stage to another. These changes can be in the minds or consciousness level of individual people. If it is at the consciousness level, it is psychological, where the mind develops a different way of thinking. This process is reflected through changes in behavior, attitude and actions or at the social and community level (community empowerment through development programmes), or in the tradition and culture of communities.

Moreover, empowerment involves the exercise rather than the possession of power and it takes place in institutional, material and discursive context involving the personal, relational and collective spheres. Empowerment can be economic, social, or political. Thus, it comprises of both the acquisition of new resources and capacities and the removal of oppressive structures surrounding the person or group. According to Borchgrevink et al (2005) empowerment means reduced marginalization, and disempowerment means increased marginalization. The concept of empowerment, according to these views, focuses at: (i) a gradual process of change of both actors and structures; (ii) power and capacity that are requisite in asserting oneself in resource access and attaining the desired human capabilities; and (iii) interactions amongst actors including the individual, household, and community.

\subsection{Micro-finance and Women Economic Empowerment}

Empowerment as a strategic development approach for women involves two levels: intrinsic and extrinsic. The extrinsic level refers to gaining greater access to and control over financial and physical resources. On the other hand, the intrinsic level involves changes within, such as the rise in self-reliance, confidence, motivation and positive hope for the future. It recognizes women's multiple roles and seeks to meet strategic gender needs through 
bottom-up participation on resources and development issues that concern the life of women.

Economic exclusion reinforces and perpetuates social exclusion. In the context of women, particularly poor women, their conditions become even more vulnerable due to unequal distribution of resources within and outside the domain of the household. Any mismatch between the minimum basic requirements and the resources available results in unfulfilled practical gender needs. In other words, poverty is the end state implying lack of entitlement emerging from insufficient assets and capabilities for the fulfillment of basic livelihood needs. This results in the social and economic exclusion of a certain class and category of people and their consequent disempowerment. Hence, the idea of 'empowerment' has influenced development practitioners, development agencies (government and non-government), theoreticians and donor agencies in the last decade (Padma and Getachew, 2004). Women's economic empowerment is thus the process, and the outcome of the process, by which women gain greater control over material and intellectual resources, and becomes less dependent on external forces. Even so, great debate tends to persist as to whether the provision of microfinance for poor women could change the social and economic equations in which this sub-set of the population live in villages, and further tend to empowerment.

\subsubsection{Controversies over Effect of Micro-finance}

Micro-finance programs are designed in aiming to provide financial services to individuals traditionally excluded from the banking system, especially women. Most micro-finance initiatives in China, as well as many programs elsewhere (most notably Grameen Bank in Bangladesh), explicitly target the poor (Park and Ren, 2001). For instance, "...the Grameen Bank now has over two million borrowers, 95 percent of whom are women, receiving loans that total \$30-40 million per month. Reported recent repayment rates average 97-98 percent. The microfinance movement has made inroads around the world and in the process poor households are being given hope and the possibility to improve their lives through their own labour" (Morduch, 1999). In response to the continuation of poverty and gender inequity in the distribution of resources, a growing literature is emphasizing planned interventions at the grass roots level and at improving the socioeconomic conditions of women. To this end, microfinance programmes are currently being promoted as a key strategy for simultaneously addressing both poverty alleviation and women's empowerment (Mayoux, 1997). The credit-based income-generating project, which mobilizes and organizes women at the grass roots level and provides access to supportive services, is becoming a leading mechanism of planned intervention for poverty alleviation (Amin et al, 1998). Often, owing to their flexibility and grass-roots level organizing ability, nongovernmental organizations (NGOs) are interested with the task of administering micro-level development programs to mitigate poverty and to enhance women's empowerment. Bangladesh is no exception to this growing trend, in which an ever increasing number of NGOs are providing collateral-free micro-credit to poor women in order to improve their livelihood and economic status (Ibid,1998).

According to Mayoux (1997), microfinance programs targeting women have been a welcome corrective to previous neglect of women's productive role. For some women in some contexts, microfinance programmes have indeed set in motion of empowerment. There are many anecdotal case studies in NGO reports of women who have shown considerable initiative, increasing their income and improving their status in the family and community, particularly after a series of loans. Similarly Park and Ren (2001), argued that such microfinance programs have increased incomes and have other positive effects, such as gender empowerment, improved nutrition, lower fertility, higher educational attainment, and reduced consumption variability.

Where financial service provision leads to the setting up or expansion of microenterprises there are a range of potential effects including: 1) increasing women's income levels and control over income leading to greater levels of economic independence; 2) access to networks and markets, giving wider experience of the world outside the home, access to information and possibilities for development of other social and political roles; 3) enhancing perceptions of women's contribution to household income and family welfare, increasing women's participation in household decisions about expenditure and other issues and leading to greater expenditure on women's welfare; 4) more general improvements in attitudes to women's role in the household and community ( Mayoux, 1997).

According to Kabeer (2001), “... these conflicting conclusions about the 'empowerment' potential of credit for women are both apparent and real. What appears to be contradictory findings concerning, for instance, the extent to which credit exacerbates or lessens violence against women, enables or fails to enable them to acquire independent assets, is associated with an increase or decrease in their living standards is partly a difference in methodology. It reflects the fact that some studies relied largely on statistical data and significance tests for their findings while others relied on more qualitative, sometimes anecdotal, evidence. Conflicting conclusions about the effect of credit also reflect differences in the questions asked by different evaluations." Finally she argued that, by and large, the negative evaluations focused on processes of loan use while the positive ones focused on outcomes associated with, and attributed to, access to loans. The validity of both sets of measures depends on their conceptual clarity and on the validity of their underlying premises.

\subsubsection{The Micro-finance Experience in Ethiopia}

A study conducted on the Dedebit Credit and Saving Institution (DECSI); found that DECSI's program has had a positive effect on the livelihoods of its clients. Compared to non-clients, clients have experienced greater 
improvements over the last five years $(2000$ - 2004). Their situation has improved in terms of income, consumption and assets. They also seem to be more food secure and less vulnerable to shocks and have a greater diversification in terms of income sources. The study found that the improvement in economic condition of the clients is a necessary condition for DECSI's program that could lead to social and political empowerment for the marginalized groups. The study also concluded that economic empowerment leads to social and political empowerment. On the other hand, this study also indicated the negative effects of DECSI's program. A considerable number of creditfinanced ventures fail with a possible effect on indebtedness and asset depletion of clients. In addition, a high level of school dropout rates of client's children is registered. This is for a purpose of shepherding animals purchased by program fund (Borchgrevink et al, 2005).

The other study was conducted on OMO and SIDAMA micro-finance institutions' women clients in Awassa town, Southern Nations and Nationalities Peoples' Regional State. According to this study, a majority of the clients are involved in the making and trading of food, and food-related products. The study also witnessed there is no diversification in their business activity. The reason for this is that the production of food and related items trade involves less risk compared to other activities. The study further found that $92 \%$ of them are not very much aware that the savings are more important than credit to build their future. The researchers' explanation of this finding is that MFI's savings policy is only to cover the risk situation rather creating any element of thrift among the clients. Nevertheless, the study argued that there is a good influence of micro credit on the urban women working groups in terms of income and self-employment generation. Furthermore, it also reflected in many cases in business improvements, decision making process and asset formation at low levels, and it is believed not sufficient (Padma and Getachew, 2004).

\subsection{Microfinance Development and Women's Participation in Ethiopia}

Up until the early 1990s, the sources of finance for rural and urban poor and micro and small enterprise operators in Ethiopia were confined only to informal sources of finance like moneylenders, friends and relatives (Itana et al, 2004). He further noted that, starting in the mid-1990s, following the drought of 1984/85, some Non-Government Organizations (NGOs) introduced the idea of saving and credit among poor people as a strategy for rehabilitation and development. Later on, special government programs operated mainly in collaboration with international financial institutions came into the picture. However, both types of programs were operated in a scattered manner and lacked sustainability until 1996.

Of the substantial measures taken to liberalize the financial sector, the promulgation of proclamation No.40/96 is most commonly cited. The proclamation provides the framework to create, expand and develop microfinance programs. Micro-financing is viewed as a means to alleviate poverty through pumping capital to subsistence agriculture and micro enterprises. Following the Agricultural Development Led Industrialization (ADLI) strategy of the EPRDF government, rural finance has been considered as an important tool for agricultural and food security (Belay, 2001). Consistent with its ADLI policy, the government had to reconsider the operational modality of microfinance to facilitate a very significant improvement in service delivery and outreach. Consequently, the government came up with Proclamation No.40 in June 1996. The central elements of the proclamation seem to be outreach and sustainability. That is, if properly implemented, the proclamation has the potential to facilitate significant outreach, and the flourishing of several sustainable Micro-finance institutions (Meklit MFI et al, 2005). After the enactment of this Proclamation, about 26 MFIs have been legally registered by the National Bank of Ethiopia (NBE), (Wolday, 2007). The importance of the micro and small enterprises sector in Ethiopia, particularly for the low-income, poor and women groups, is evident from their relatively large presence, share of employment and small capital requirement. These are sufficient reasons for governments and other stakeholders in development to be interested in micro and small enterprises (Gebrehiwot and Wolday, 2001). In line with the development of micro-finance institutions, the Government of Ethiopia set up participatory rules and policies which gave space for women productivity.

Consequently, all development programs at national and regional levels should be able to integrate gender concerns in their plans and programs to ensure that women participate, contribute, benefit, become recognized, and obtain technological support. Rural development programs need to reorient their implementation strategies so that they would target rural women as beneficiaries of development initiatives and programs. Within this framework, anti-poverty and women empowerment could be aspects of the major development strategies. Ethiopian MFIs have served 1,211,305 clients nationwide up to June 2005. The loan portfolio in the hands of active clients was about $\mathrm{Br} 1.5$ billion (173 million USD). The average loan size was about $\mathrm{Br} .1000$ (116 USD).Ethiopian microfinance industry is dominantly serving the rural poor. About 38 percent of clients of the MFIs are female (Wolday, 2007). As the overriding objective of MFIs in Ethiopia is to provide a broad range of micro-finance services to large numbers of poor households, it should be their (MFIs') priority to accommodate remarkable numbers of women clients to accomplish tangible changes in the livelihood of the rural poor. 


\section{METHODOLOGY}

Description of the Study Area. This study was undertaken in Lemo District which is one of the 10 rural Districts of Hadiya Administrative Zone in Southern Ethiopia

Data Sources, Sampling and Data Collection: To select sampled respondent farmers, two-stage simple random sampling technique was employed. Use of administrative units is necessary to select representative study sites within the District. The smallest administrative unit in the District is Kebele. There were 33 Kebeles in the District. Four Kebeles namely: Ambicho Gode, Jawe, Shurmo and Gidisa were randomly selected. The reasons for choosing the simple random sampling technique are its simplicity and existence of similarity in farmers' socioeconomic conditions in all midland Kebeles of the District. Thus, those chosen kebeles were assumed to be representative of Lemo district. By taking the list of farm household heads from each selected Kebeles as a sample frame, 156 representative farm household women were randomly selected in probability proportion to size of each Kebele's population (Table 1). The micro-finance programe users and non-users were included in the sample. Representative sample size was determined using the formula which is developed by Yamane (1967): $n=\frac{N}{1+N(e)^{2}}$

Where, $n$ is sample size, $N$ is target population and e is level of precision, in this case it is $9 \%$. Table 1. Total number of the sampled farmers and population in the sampled kebeles

\begin{tabular}{lcc}
\hline Kebele & Total number of households & Sampled womens \\
\hline Ambicho Gode & 889 & 39 \\
Jawe & 904 & 39 \\
Shurmo & 922 & 40 \\
Gidgisa & 875 & 38 \\
Total & 2715 & 156 \\
\hline
\end{tabular}

Source: Own computation, 2017 from LDOARD

Methods of Data Analysis: Descriptive statistics like means, frequencies, percentages, maximum, minimum, and range were used to describe the descriptive result while binary logistic regression model were employed to identify the intensity of food insecurity and coping strategies.

Specification of the models: The Logit model is applied in determining women's economic empowerment since the empowerment indicator, i.e., the dependent variable (decision-making on large sales) is dichotomous. The observable variable, decision making on large sales, is used as a proxy to judge whether or not economic empowerment actually exists that is unobservable to the researcher. If we state the regression equation as:

$Y i^{*}=\beta \mathrm{Xi}+\mu \mathrm{i}$

Where $\mathrm{Yi}^{*}$ is the unobservable variable, which is estimated by the dummy variable $\mathrm{Y}$, which takes a value equals 1 (thus $\mathrm{Yi}^{*}$ exists), otherwise 0 (thus $\mathrm{Yi}^{*}$ does not exist); $\beta$ is the parameter to be estimated; $\mathrm{Xi}$ is the independent variable; and $\mu \mathrm{i}$ is the unobserved error term. With this formulation, for the independent variables (most of them are dummy in our case) which are not normally distributed, the Logit maximum likelihood estimators are consistent and more robust (Maddala, 1999:27). In qualitative response models the dependent variable is an indicator of a discrete choice (Greene, 2003). Decision making on household large sales, as dichotomous dependent variable, takes the value of 1 if the respondent says 'I can decide to sell goats/sheep by myself' otherwise, 0 . The probability of women clients to be empowered $(\mathrm{Pi})$ can be given as:

$\mathrm{Pi}=\operatorname{Pr}(\mathrm{Y}=1)=\mathrm{E}(\mathrm{Y} / \mathrm{Xi})=1 /(1+\mathrm{e}(\beta 1+\beta 2 \mathrm{Xi}))$

if $\mathrm{y}=1$, women clients decide on large sales (economically empowered); and if $\mathrm{y}=0$, then the women clients do not decide on large sales alone (not economically empowered); $\mathrm{E}(\mathrm{Y} / \mathrm{Xi}$ ) is the expectation that a woman client decides on large sales (economically empowered) given the values of exogenous variables (Xi), where betas are the parameters to be estimated.

The value of $\beta$ (the coefficient) determines the direction of the relationship between the explanatory variables $\mathrm{Xi}$ and the dependent variable $\mathrm{Yi}$. When $\beta$ is greater than zero, larger (or smaller) $\mathrm{Xi}$ values are associated with larger (or smaller) of Yi. Conversely, if $\beta$ is less than zero, larger (or smaller) Xi values are associated with smaller (or larger) of Yi (Peng et al, 2002). However, the parameters of the model, $\beta$ are not marginal effects as is the case in linear regression models. In discrete choice models like the logit model, where most of the explanatory variables are dummy, it requires to calculate the marginal effects of the variables separately. The calculated marginal effects must not be also interpreted as 'a small change' of $\mathrm{Xi}$, since it is rather the effect of change in a dummy variable (say from 0 to 1 ) or change of state (Greene, 2003).

The Logit model is based on the logistical curve, for all values of the regressors. This is a more realistic pattern of change in the probability compared to other Qualitative Dependent Variable Models like the Probit, for two reasons. First, the odds ratio, which is a measure of the strength and direction of relationship between the two variables, has a special property of not requiring variables to be normally distributed. Second, a mathematical transformation of the odds ratio is the logit model. This mathematical transformation removes the problem of 
asymmetry existing in the odds ratio and in turn makes this a superior method (Peng et al, 2005).

Formulation of the Empirical Model and Description of the Variables: Decision making on household large sales is the dependent variable used to study the economic empowerment of women clients. It is hoped to capture empowerment in practice (as opposed to rhetoric) as expressed through their role in the decision to sale major household assets such as oxen, cows etc. This indicator (decision making on household large sales) is one of the eight selected empowerment indicators in the 1996 study by Hashmi et al. For the purpose of the present study, "large sales" indicates "the sale of goats and/or sheep".

We were resorted to using the role of women in the sale of goats and/ sheep as economic empowerment indicator is selected because of two reasons. First, using other larger household assets such as oxen and camels would be problematic because the majority of the respondents may not own such assets. Second, using miscellaneous household assets would also be problematic because they are normally left to women, hence may not indicate empowerment status. Thus, decision-making on the sale of goats and/or sheep is considered as a reasonable indicator which minimizes the above problems. The question of decision-making on household large sales is expressed in dichotomous form for different scenarios. Thus, a "women alone decision" is assigned a value of 1, otherwise 0. The Economic Empowerment Function of this study is defined as:

DMLS=f (BCMF, RLE, HHHEAD, AFRA, AYHI, LOS, PCS, HO)

Table 2 Definition of variables and the expected sign of explanatory variables

\begin{tabular}{|c|c|c|}
\hline Variable Name & Definition of Variable & Expected Sign \\
\hline \multicolumn{3}{|c|}{ Dependent variable } \\
\hline DMLS & Decision making on large sales (dummy, if yes $=1$ ) & \\
\hline \multicolumn{3}{|c|}{ Independent variables } \\
\hline BCMF & Being Client of MF (dummy, if matured=1) & $+/-$ \\
\hline RLE & $\begin{array}{l}\text { Respondent's Level of Education (categorical, } \\
\text { illiterate }=0 \text {, read and write }=1, \mathrm{G} 1-4=2, \mathrm{G} 5-8=3 \text {, G 9- } \\
12=4\end{array}$ & + \\
\hline HHHEAD & $\begin{array}{l}\text { Household head (dummy, if woman is household } \\
\text { head = 1) }\end{array}$ & + \\
\hline AFRA & $\begin{array}{l}\text { Animal fattening and rearing activities as an alternative } \\
\text { occupation (dummy, if yes }=1 \text { ) }\end{array}$ & + \\
\hline AYHI & $\begin{array}{l}\text { Average yearly household income of respondents } \\
\text { (continuous) }\end{array}$ & + \\
\hline LOS & $\begin{array}{l}\text { Loan from other sources other than MFIs (dummy, if } \\
\text { yes }=1 \text { ) }\end{array}$ & + \\
\hline PCS & Existence of personal cash savings (dummy, if yes $=1$ ) & $+/-$ \\
\hline $\mathrm{HO}$ & $\begin{array}{l}\text { Home ownership ( categorical, If no }=0 \text {, " gojo" }=1 \text {, } \\
\text { "yesar adarash" }=2 \text {, "korkoro bet" }=3 \text {, more than one } \\
\text { type }=4\end{array}$ & + \\
\hline
\end{tabular}

Maximum Likelihood Estimation estimates the above model and the analysis is carried out using the statistical package, STATA 11.

\section{RESULTS AND DISCUSSION}

\subsection{Results of Descriptive Statistics Analysis.}

In this study, the results obtained from descriptive and econometric analyses. In the descriptive statistics mean, percentages, standard deviations were computed in the process of examining and describing socioeconomic and demograghic characteristics on the effect of Micro-finance on Women's Economic Empowerment. Moreover, ttest and chi-square test were computed to make comparisons between different groups of actors with respect to the characteristics under consideration. The econometric analysis was employed to assess the effect of micro-finance on women economic empowerment.

The study showed that $87.4 \%$ of the sample households were male-headed households and $12.6 \%$ were female-headed. The average age of the sampled respondents was 47 years. Family size is a distinguishing characteristic in rural communities of many developing countries such as Ethiopia (Mamo, 2009). The case is similar in the study area; the household heads interviewed had a family size ranging from 2 to 16 and the average family size was found to be 6.24 persons (Table1 ).

All the matured clients that are married, who also headed their respective households, reported that they considered themselves as household heads on account of the fact that they took the main decisions when it came to major household decisions. According to them, this happened because participation in the loan programme helped them to generate income and own resources in the household. Regarding the educational level attained, the majority of respondents $(61 \%)$ were illiterate and none of the respondents completed 12 th grade. $65 \%$ of the 
matured clients, $49 \%$ of the incoming clients and $50 \%$ of the non- clients in programme areas, and $71 \%$ of nonclients in non-programme areas, and $58 \%$ of dropouts were illiterate (Table 1).

Table 1. Socio-economic characteristics of respondents

\begin{tabular}{lllll}
\hline Continuous variables & $\begin{array}{l}\text { clients } \\
(\mathrm{n}=102)\end{array}$ & Non- clients $(\mathrm{n}=54)$ & $\begin{array}{l}\text { Overall } \\
(\mathrm{n}=156)\end{array}$ \\
\cline { 2 - 4 } & Mean & Mean & Mean & $\chi^{2}$-value \\
\hline Age & 46.53 & 47.81 & 46.96 & 1.19 \\
Family size & 6.43 & 6.09 & 6.24 & -0.96 \\
Education level & 5.43 & 4.83 & 5.23 & -0.56 \\
\hline Dummy variables (yes, \%) & $(\%)$ & $(\%)$ & $(\%)$ & $\mathrm{t} / \chi^{2}$-value \\
\hline Sex & & & 87 & $4.16^{* *}$ \\
Market information & 85 & 92 & 68 & $116.6^{* * *}$ \\
\hline
\end{tabular}

$* * *, * *$ and $*$ represents significance at $1 \%, 5 \%$ and $10 \%$ probability levels, respectively.

Source: Own computation of survey data (2019)

\subsection{Assessing the effect of Micro-finance on Women's Economic Empowerment}

In order to evaluate the effect of Micro-finance intervention in the study area, respondents' current average yearly household income, asset possession, personal voluntary cash savings and participation in household decisionmakings were considered. To determine the effect of the programme, current average yearly household income of respondents were recorded. Accordingly, the higher proportion of clients, $44 \%$, fall with the income range of Birr 5000 - Birr 10,000 birr; whilst of the total clients, $13 \%$ earn yearly household incomes of above Birr 10,000.00. On the other hand, the majority of them, $85 \%$ of these non-clients earn an income of less than Birr 5000.00 while only $15 \%$ of matured clients earn above Birr 5000.00 an income per year. The resulting data indicates that, most clients are in the high income level range (relatively) when compared with the other category of respondents (Table 2 ).

Table 2 Average Yearly Household Income of Respondents

\begin{tabular}{|l|l|l|l|l|l|l|}
\hline Level of Income in & Below & $1001-$ & $2501-$ & $5001-$ & Above & Total \\
\hline Birr & 1001 & 2500 & 5000 & 10,000 & 10,000 & \\
\hline Non- Clients & 1 & 2 & 41 & 45 & 13 & 102 \\
\hline
\end{tabular}

\begin{tabular}{lllll}
\hline Continuous variables & $\begin{array}{l}\text { clients } \\
(\mathrm{n}=102)\end{array}$ & Non- clients $(\mathrm{n}=54)$ & $\begin{array}{l}\text { Overall } \\
(\mathrm{n}=156)\end{array}$ & t-value \\
\cline { 2 - 4 } & Mean & Mean & Mean & \\
\hline Income & 11420.70 & 4050.85 & 6550.80 & $18.34 * * *$ \\
\hline
\end{tabular}

$* * *, * *$ and $*$ represents significance at $1 \%, 5 \%$ and $10 \%$ probability levels, respectively.

Source: Own computation of survey data (2019)

Thus, average yearly income of matured clients is higher than the income of incoming clients and non-clients; especially the mean difference of Birr 7, 369.85 between clients and non-clients in the areas is quite large. The ttest result also indicated that there is a significant mean difference between clients and non- clients at less than $1 \%$ probability level in terms income.

The the microfinance programme has had a positive effect on improving the income of women clients; especially the clients who managed to improve their household income levels significantly after obtaining a series of loans. Increasing women's income levels and control over income leads to greater levels of economic independence. Thus, the contribution made by these women towards increasing the overall household income enables them to participate in household decision making about expenditure and other issues. It is an indication of women's economic empowerment.

\subsection{Effect on Asset Possession}

In order to determine the impact of the microfinance program on asset possession, some selected household assets of respondents of significant price and value were registered. Accordingly, of the total matured clients, about $83 \%$ own at least one ox/cow/camel; $39 \%$ own at least one goat or sheep; $15 \%$ own a tape/radio player; and, $30 \%$ own frame-beds. Similarly, amongst the total incoming clients, $33 \%$ own at least one ox/cow/camel, 33\% own at least one goat or sheep; $18 \%$ own a tape/radio player; and, $12 \%$ own frame beds. Of the total non-clients in program areas, $57 \%$ own at least one ox/cow/camel and $12 \%$ own at least one goat/sheep; whilst in non-program areas, $14 \%$ of non-clients own at least one ox/cow/camel and $16 \%$ own at least one goat or sheep. Also, $13 \%$ of incoming clients owned a tape/radio player and $25 \%$ of incoming clients also own frame beds, whilst none of the non-clients in non-program areas owned any of the aforementioned assets. (See Table 2) Thus, the study results 
suggest that matured clients of the program have better asset possession, especially livestock.

House (home) improvement and repair was also used as an indicator of the asset possession level of respondents. Amongst 54 matured clients, 11 of them were not home-owners before joining the loan program but 7 of them were able to construct their own homes; with 4 of them building 'Yesar Gojo' (thatched hut) and 3 of them 'Korkoro bet' (proper house with galvanized roof) after joining the program. The respondents explained that they constructed their houses with funds generated from the loan-financed business activities. Among the 43 matured clients who were home-owners before the program, 13 of them made several home improvements or any additions, which cost more that Br. 100.00 at a time, within the past three years (1997, 1998 and 1999 E.C.). 4 of them constructed an additional 'Korkoro bet' whilst 3 of them constructed additional 'Gojos'. The rest 3 repaired their houses and the other 3 made the household improvement of connecting electricity power to their houses. The respondents indicated that the higher proportion of these home improvement and repair costs were covered by the income generated from loan financed business activities. On the other hand, amongst 33 incoming clients, 6 had no homes before joining the loan program, but 1 of them was able to construct a 'Korkoro bet' after joining the program. In addition, amongst 27 who were home-owners before joining the program, 2 of them made improvements to their houses within the current year. Surprisingly, the clients used the loan money itself to carry out the above activities. Regarding non-clients, only one from the program area and one from the non-program area made improvements to their houses over the past three years. And the reason they gave for not many any home improvements or additions or carrying out any repairs is simply lack of money.

The participation of women in the micro finance program substantially contributes to an improvement in their asset possession compared to non-clients. By providing them with an independent source of income outside the home, the loan program tends to reduce the economic dependency of women on the household. In addition to the loan fund, income from business activities financed by the loan has helped the women clients to purchase certain assets as well as financing some home improvements, thus assisting to enhance financial independence. Thus, the increased control over asset ownership and material resources that has been made possible by the loan program should also translate into raising the self-esteem and prestige of these women when it comes to household decisionmaking. Accordingly, $61 \%$ of matured clients rated the impact of the micro finance program on personal asset ownership and control as "very high", whilst $30 \%$ rated the impact as "high", thereby pointing to the fact that the intervention of the program has a positive impact on women's economic empowerment. (See Table 2)

\subsection{Effect on Savings Habit}

Savings can be used in case of emergencies, or to finance major purchases, investments or to smoothen out consumption. Of the total number of clients surveyed, $50 \%$ of matured clients; $45 \%$ of incoming clients; and, $13 \%$ of non-clients in program areas maintain voluntary personal cash savings, whilst only $12 \%$ of non-clients in non-program areas maintain voluntary personal cash savings (See Table 3). Among the 27 matured clients and 15 incoming clients who have voluntary personal cash savings, 16 of the matured clients indicated that the source of their cash savings is profit generated from loan-financed business activities, whilst 5 incoming clients confirmed that they were able to maintain cash savings from loan-financed business activities.

Table 3 Distribution of Respondents by Level of Voluntary Personal Cash Saving

\begin{tabular}{lllllll}
\hline Level of Cash Saving Vs. No. of & Below & $1001-$ & $5001-$ & Above & Total \\
Respondents & 1000 & 5000 & 10,000 & 10,000 & Respondents & No.of \\
\hline Matured Clients & 5 & 13 & 29 & 45 & 92 \\
Incoming Clients & 2 & 3 & 3 & 2 & 10 & 54 \\
Non-Clients & 2 & 7 & 35 & 10 & 54 \\
\hline
\end{tabular}

Source: Own computation of survey data (2019)

Regarding the depository where respondents kept their saved money, 10 of the matured clients, and 2 of the incoming clients put their money in savings accounts maintained with micro finance sub branch offices. It is important to note that none of these women had savings accounts before participating in the micro finance program. The rest of the matured and incoming clients and all non-clients kept their money in the form of Ikube (rotating group savings scheme), and kept at home. The main reason for the incidence of a significant number of matured and incoming clients who have personal cash savings is the level of exposure made possible by the loan program in terms of the training provided to participants. This helps to create initial awareness about the need to maintain savings. Similarly, the obligatory saving process inherent in the loan program gives the clients the requisite experience on how to practice voluntary savings. Moreover, clients may save their money easily with micro finance offices where they are already familiar, whilst the income generated from loan-financed business activities provides clients with an opportunity to save.

Thus, saved money would help women clients to expand their businesses and to invest on new activities which could lead them to increase their income sources. In addition, women can also use the saved money to make major purchases for the household. This contribution of women in household income, and share of expenditures will enhance the financial independence of women within the household, which in turn increases the level of 
participation of these women in household decision-making.

Thus, the loan program improves the savings habit of women which enables them to be more financially independent. Of the total matured clients, $38(70 \%)$ rated the impact of the micro finance microfinance program in helping to improve their savings habit and exercise control over their savings as "very high"; whilst 10 $(19 \%)$ of the matured clients rated the impact of the program on their savings habit as "high". Only 2 respondents indicated that the program has had no impact on their savings habit. (See Table 3)

\subsection{Effect on Household Decision-Making}

The participation status of women in household decision-making is the overriding indicator of women's economic empowerment. To examine the impact of the microfinance program on women's decision making within the household, respondents were asked to indicate their decision making status in different household activities such as sale of animals, purchase of household utensils, clothing items, women's garment and ornaments, and decision on school expenses. Accordingly, 15\% of matured clients who are widowed or divorced women reported that they made independent decisions to sell ox/cow without any consultation with male relatives, whilst all the matured clients that were married women confirmed that they made the decisions in consultation with their husbands, and as such it was a mutual decision. On the other hand, most non-clients who were married women did not play any important role in such decision-making.

In this case, their husbands solely took the decision and just informed them after the fact. Similarly, when it is time to decide on buying household clothing items, women's garments and ornaments, and school expenses, matured women clients are better suited to making decisions than the incoming clients and non-clients. On the other hand, there is no real difference in decision-making on household utensils because these usually fall within the purview of women's housekeeping activities. Regarding decision-making on the sale of goats and sheep, 43 $(80 \%)$ of the matured clients; 16 (48\%) of the incoming clients; $6(38 \%)$ of the non-clients in program areas; and, $15(36 \%)$ non-clients in non-program areas are able to make independent decisions without consulting other parties. Table 4. Distribution of Matured Clients by their Response on effect of micro finance Programme

\begin{tabular}{lllllll}
\hline Level of effect Vs Frequency & Very High & High Medium & Low Very & Low & No effect & No Idea \\
\hline $\begin{array}{l}\text { On Increasing Income and } \\
\text { Control Over Income }\end{array}$ & 45 & 3 & 1 & - & - \\
$\begin{array}{l}\text { Effect on Access to and } \\
\text { Control Over Asset }\end{array}$ & 25 & 6 & 3 & - & - \\
$\begin{array}{l}\text { On Improving Saving Habit } \\
\text { and Control Over Saving }\end{array}$ & 25 & 31 & 9 & 1 & - & - \\
On Household Decision & 41 & 28 & 7 & 2 & - & - \\
Making
\end{tabular}

Source: Own computation of survey data (2019)

Thus, the matured clients of micro finance are better decision makers on household large sales and handling expenses when compared with the other category of respondents. This enhanced decision-making position of women seems to have resulted through the overall effect of the loan program which, has helped to improve the income and asset possession status of women clients within the household. Women's contribution to household income and family welfare leads to a more general improvement in attitudes towards the role of women within the household and within the community. Regarding the effect of the micro finance program on women's household decision-making, $40(74 \%)$ of the matured clients, rated the impact of the micro finance program as having helped to improve their status on household decision-making as "very high". Similarly, 10 (19\%) of them indicated the impact as "high", whilst 4 (7\%) of them rated the micro finance program as having had a "medium" (moderate) impact on their household decision-making status. (See Table 3). In addition to the observation made by active clients, dropouts were also asked to rate the impact of the microfinance program on their life. Accordingly, among the 26 dropouts $15(58 \%)$ of them rated the loan program as having helped their family immensely (a lot), whilst 7 of them rated the loan program as having helped their family a little. On the other hand, 3 of respondents indicated that the loan program did not help them at all, and one respondent indicated that the loan was even a burden on her. (See Table 4) 


\section{Estimation of the Logit Model and Analysis Result}

Table 5 Binomial Logit Estimates for Decision-Making on Large Sales

\begin{tabular}{llll}
\hline Variables & Coefficient & Marginal Effect & $\mathrm{P}>|\mathrm{z}|$ \\
\hline BCA. & 1.59 & .361 & $0.000^{* * *}$ \\
RLE & .236 & .0581 & 0.414 \\
HHHEAD & 1.231 & .297 & $0.012^{* * *}$ \\
AFRA & 1.024 & 2.66 & $0.029^{* *}$ \\
AYHI & $-1.08 \mathrm{e}$ & .233 & 0.988 \\
LOS & -.479 & -.119 & 0.367 \\
PCS & .0481 & .0111 & 0.914 \\
Constant & -1.566 & & 0.006 \\
\hline
\end{tabular}

Source: Own computation of survey data (2019)

$* * *, * *$, variables significant at $1 \%$ and $5 \%$ level of significance respectively Marginal effect is discrete for dummy variables. Log pseudo likelihood $=-50.610927$, Number of obs $=97$, Wald chi2 $(8)=25.56$, Prob $>$ chi2 $=0.0011$ Pseudo R2 $=0.2183$

The Binomial Logit model estimates were made in order to determine factors that affect decision making on large sales. The estimation was made by proposing three different scenarios by taking matured clients as intervention group and the other client categories (incoming clients, and non clients in program and non-program areas) as alternative control groups. The scenarios constructed were; first, a comparison between matured clients versus incoming clients, non clients in program and non-program areas combined. The second comparison was between matured clients and incoming clients. Finally, the matured clients were compared with non clients in nonprogram areas.

The problem of heteroscedasticity which is mostly inherent in cross-sectional data was checked before estimation of the model, and correction was made with respect to heteroscedasticallyconsistent standard errors. Thus, the reported overall significance of the model as seen from the pseudo R2 and chi square is significant. The three variables; being a client of micro finance; being a household head; and, engaging in animal fattening and rearing activities are positively related to the decision-making on large sales (decision-making on the selling of goats and sheep), in all of the three scenarios. In the first scenario, the coefficients of these three variables are significant at the $1 \%, 1 \%$ and $5 \%$ levels of significance respectively. While the coefficients of the former two variables are statistically significant at the $5 \%$ and $1 \%$ levels of significance, respectively, the latter variable is statistically insignificant in the second scenario. On the other hand, the coefficients of the former and the latter (being client of micro finance and engaging in animal fattening and rearing activities) variables are statistically significant at the $1 \%$ and $5 \%$ level of significance, respectively, but the coefficient of household head variable is statistically insignificant in the third scenario (See Table 5)

As can be observed in the first scenario, the variable, being a client of micro finance is highly imperative in determining decision-making on large sales. The loan fund itself, income from loan financed activities, and micro finance training on how to handle and control loan financed activities provides an opportunity to women clients to acquire their own assets, and to develop confidence on making important decisions on large sales and purchases over time. Thus, the possibility of matured women clients having to own and exercise control over assets within the household (which has the effect of reducing women's dependency) will lead them to economic empowerment. This implies that matured women clients of micro finance are more empowered than incoming clients and non-clients. The case is the same for the third scenario where the coefficient of the variable, being a client of micro finance is also highly significant (at the $1 \%$ level of significance) in determining decision making on large sales, thereby implying that matured clients are more empowered than the non-clients in non-program areas because of the availability of the loan services availed by the micro-finance program.

The coefficient of the variable, being a client of micro finance, is relatively less significant (at the $5 \%$ level of significance) in the second scenario than in the first and third scenarios. But this does not mean that the variable is weak in helping to determine decision-making on large sales, rather, this might have happened due to the nature of the control group which also consists of clients of the microfinance program. Though these clients are incoming (having only participated in the program for one year or less than a year) and the program is therefore not expected to have any appreciable impact on them as the matured clients, the program happens to have some effect on these clients. So the relative decline of the coefficient of the variable indicates that the micro finance service has an impact on both matured and incoming clients which enables them to independently make decisions on large sales. At the same time, it is indicated that effect of the program on matured clients, which enables them to make decisions on large sales is higher than the incoming clients, thereby making the matured clients to be more economically empowered than the incoming clients(See Table 5). In the first and second scenarios, the coefficient of the variable, household head is statistically significant at the $1 \%$ level of significance, and positively affects decision-making on large sales. Female who are heads of their households might already have initial exposure to independently make decisions on large sales without being dominated (or influenced) by a husband or close adult 
male relative.

The other variable, animal fattening and rearing activities, positively determines decisionmaking on large sales in the first and third scenarios at the $5 \%$ level of significance. In the result obtained, matured clients are better decision makers than the other respondents. This is because, the possibility of matured women clients to engage in animal fattening and rearing activities is very high, since these activities are the main intended purposes of the micro finance loan program. The accessibility of loan fund and income which is generated from loan financed business activities, and the training provided, which helps the clients to know how to practice such activities will definitely women to purchase animals for fattening and rearing; taking the responsibility to care and raise these animals to maturity; and, to make the independent decision to sell these animals when the need arises. Thus, the loan program helps matured women clients to make decisions on large sales, and as such, they are more economically empowered than non-clients of the microfinance program. The rest of the variables that are hypothesized as influencing decision making on large sales are unexpectedly found to be statistically insignificant. These are; respondent's level of education, average household yearly income, loan from additional sources other than MFIs and personal cash savings.

\section{CONCLUSIONS AND POLICY IMPLICATIONS}

Women in Ethiopia are marginalized from economic, social and political empowerments due to multifaceted reasons. As a viable approach to poverty alleviation and development, microfinance is designed to assist the poor, particularly women, to bring about economic empowerment across the globe, though the Ethiopian experience remains open for further study and investigation. As such, the present study assesses the impact of microfinance on women's economic empowerment, taking the case of Lemo district (micro finance) in Southern Regional State, Ethiopia.

To implement the study, primary and secondary data sources were used. The survey used cross sectional design. 8 rural Kebeles; 6 from program areas and 2 from non-program areas were selected using stratified random sampling technique. A total sample of 171 rural women; 54 matured clients, 33 incoming clients and 26 dropouts, 16 and 42 non-clients in program and non program areas respectively were selected from the 8 studied Kebeles using random sampling technique. Primary data was collected through structured questionnaires, group-focused discussions, interviews and informal discussions; and the data was then analyzed using both descriptive and analytic methods. A binomial logit model was employed to identify the determinants of decision-making on large sales (as an economic empowerment indicator in the study) by comparing matured clients with three different control groups in three different scenarios.

According to the findings from the study, micro-financing has yielded positive impacts on women's economic empowerment. The majority of matured women clients of micro finance have improved their access to and control over assets. In this regard, women now own and control economic assets such as livestock and better dwellings. In addition, clients have improved their households through income generated from loan-financed activities. Asset possession of matured clients has been found to be better when compared with incoming clients and non-clients of similar category.

Women's participation in the micro finance micro-finance program has also contributed substantially to the improvement of their income. Matured clients have been found to be in better socio-economic status, in terms of their increased income levels and control over their earnings, when compared with the incoming clients and nonclients. The loan program helped clients to diversify their sources of income by practicing income-generating activities such as animal fattening and rearing activities, which are useful indicators of decision making on large sales in the regression model. In similar manner, the loan program improved the saving habit of women clients and the control such women now exercise over their savings. The majority, $50 \%$ of matured clients, now have personal cash savings, which shows a considerable difference when compared with non-clients. The effect of micro finance intervention on the participation of women in household decision- making is very significant. The decisionmaking role of women clients has improved over time. Thus, most of the matured clients are now able to make decisions by themselves on large sales, such as the sale of oxen, cows, goats and sheep; and on expenses for household items like clothing and garment, self-ornaments and other items of adornment, and school expenses. It was also observed that the matured clients of micro finance were found to be better in making decisions on the sale of goats and sheep in the household, the typical economic empowerment indicator used for the study. On the other hand, married women clients were less decision maker on household large sales than widowed and divorced women.

In general, this study has revealed that decision making on large sales as an indicator of women's economic empowerment is positively correlated with the micro-finance service program. Thus, the implication of this study is that, though additional efforts are needed, micro-financing service that is being rendered by the Lemo district microfinance institution has been contributing positively towards improving the socio-economic status of women, and has impacted on women's economic empowerment in the study area. 


\section{REFERENCES}

Ackerly, B.A. (1991). Testing the Tools of Development: Credit Programmes, Loan Involvement, and Women's Empowerment. ids bulletin 26(3), 56-68.

Amhara Credit and Saving Institution (ACSI), (2004a). Institutional profile, Current status and Future Strategy Report. Bahir Dar, Ethiopia.

, (2004b). First General Assembly Proceeding. Bahir Dar, Ethiopia.

Amin, R., Becker, S., and Bayes,A. (1998). NGO-Promoted Microcredit Programs and

Women's Empowerment in Rural Bangladesh: Quantitative and Qualitative Evidence. The Journal of Developing Areas, 221-236.

Belay Asefa (2001). Best practices in Microfinance: Lessons to Ethiopia. A paper presented on International workshop on microfinance, Mekelle University, Ethiopia.

Institution (DECSI) of Tigray, Ethiopia; Occasional Paper No. 14, Addis Ababa, Ethiopia.

Central Statistical Authority (CSA), (1994). Ethiopian Census on Housing and population. Addis Ababa, Ethiopia. , (1998). The 1994 Population and Housing Census of Ethiopia: Summary Reports at Country and Regional Levels. Addis Ababa, Ethiopia.

Dunford, C. (2000) "In search of "Sound practices" For Micro Finance." Journal of Microfinance, 2(1).

Gebrehiwot Ageba and Wolday Amha (2001). Micro and Small Enterprises (MSE) development in Ethiopia: Strategy, Regulatory changes and remaining constraints. Ethiopian journal of economics 10(2), 1-32.

Greene, W.H., (2003). Econometric Analysis, 5th ed. Pearson edition, India.

Hashemi, S.M., Schuler, S.R. and Riley, A.P. (1996). Rural Credit and Women's Empowerment in Bangladesh. (in: World Development, JSI Research and training Institute). Virginia, U.S.A.

Hossain, M. (1884). The effect of the Grameen Bank on Women's involvement in productive activities, back credit for landless women. A study tour of Grameen Bank, Dhaka.

Hunt, J. (2002). Reflections on microfinance and Women's empowerment. Nalini Kasynathan, Oxfam Community Aid Abroad, South Asia.

Itana Ayana, Tsheay Tsegaye, Eshetu Erena and Wolday Amha (2004). Governance and Ownership Structure of Microfinance Institutions in Ethiopia. Microfinance development Review, 3(2).

Kabeer, N. (1998). Can't buy me love? Re-evaluating gender, credit and empowerment in rural Bangladesh. IDS Discussion Paper No.363.

Kobo Woreda Administration Office, (2006). Kobo Woreda's Socio-Economic Review. Kobo, Ethiopia.

Matienzo. R. (1993) .Loan Profitability and Effect in the RD-12 Project. Dhaka: Canadian Resource Team.

Mayoux, L. (1997). The Magic Ingredient? Microfinance and Women's Empowerment. A briefing paper prepared for Micro Credit Summit. Washington, U.S.A.

(1999). From Access to Empowerment: Gender Issues in Micro-Finance. A paper presented to CSD virtual conference. Washington, U.S.A.

(2001). Tackling the dark side: Social Capital, Women's empowerment and microfinance in Cameroon, Development and Change. Journal of International Development, 82

(2002). Micro finance and Women's empowerment: Rethinking 'best practice'. Development Bulletin, $57,76-81$

Meagher, p and Wilkison, B (2000). "Towards A Market - Friendly Environment for Microfinance: Legal and Regulatory Reforms in Zambia" Small Enterprise Development. An International Journal of Microfinance and Development (11) 4, 24-29.

Meklit Microfinance institution, Progynist and Alisei NGO (2005). "Credit and education for Exit Interview from Africa And Asia." The Micro Banking Bulletin, 6, 35-40.

Narayan, D (2002). Empowerment and Poverty Reduction: A Source Book. Washington, DC, The World Bank.

Noponen, H. (1990). Loans to the working Poor: A Longitudinal Study of Credit, Gender and the Household Economy. PRIE Working Paper No.6.

Otero, M (1999). "Bringing Development Back, in to Micro finance.” Journal of Micro Finance 1(1).

Padma, M. and Getachew Ayele (2004). Women Economic Empowerment and microfinance: http://www.mip.org Sorensen, P. (2001). Food Security and non-Farm Development: Policies, Programmes, and Prospects in North Wollo, the Amhara Region, Ethiopia. Centre for Development Research, Copenhagen.

USAID (2005). Amhara Credit and Saving Institute: Ethiopia.

Wolday Amha (2007). Managing Growth of Microfinance Institutions (MFIs): Balancing Sustainablity and Reaching Large Number of Clients in Ethiopia. Occasional Paper No..

Women's Affairs Office (1998). Implementing the Ethiopian Policy for Women: Institutional and Regulatory Issues. Addis Ababa, Ethiopia

Yeshiwas Mengesha and Mulugeta Seyume (1999). Report on Irrigation Schemes Performance and Basic Problems', part two. Amhara Regional State, Kobo-Girana Valley Project, Kobo. 